\title{
Governance at the Local Level in Melanesia - Absent the State
}

Commonwealth Journal of Local Governance

Issue 3: May 2009

http://epress.lib.uts.edu.au/ojs/index.php/cjlg

\section{David Hegarty}

Visiting Fellow

State, Society \& Governance in Melanesia Program

Research School of Pacific \& Asian Studies

Australian National University

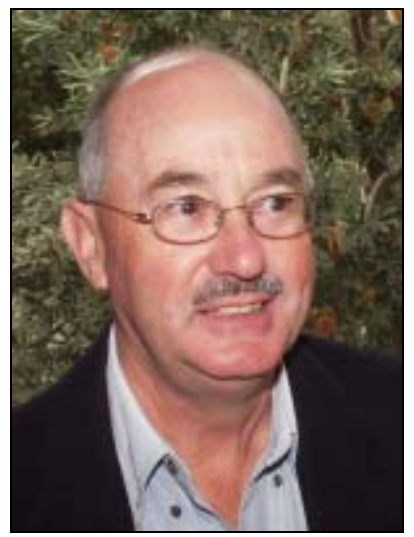

\section{Introduction}

At independence the three Melanesian states of the Pacific Islands region - Papua New Guinea (1975), Solomon Islands (1978) and Vanuatu (1980) - opted for decentralised systems of government. In all cases a three-tier system of national, provincial and local government was introduced, although the specific arrangements and allocation of powers differed substantially. Since that time there has been a good deal of analysis about the policy processes of decentralisation itself and about the effectiveness (or otherwise) of national-level governance in these countries; but until recently little has been written about the lower levels.

This short article surveys some of the recent research and commentary on local-level governance relating particularly to Papua New Guinea (PNG) and Solomon Islands. It focuses on both the poor condition of formal local-level government as well as on the rise of informal governance-type activity at the local level which might be described as 'civil society in formation'. 
It is clear in these two countries that the formal institutions of Local Level Government (LLG) - with a small number of notable exceptions in PNG - have not worked well nor gained much traction as effective instruments of administration and service delivery within the communities they were established to serve. In some ways this is a surprising result given the famed diversity of Melanesia's small-scale socio-political units which, together with fissiparous tendencies evident in the late colonial period, led observers at that time to the view that these countries were ripe for the transplantation and uptake of local-level forms of government.

LLGs, however, quickly became very much the 'poor cousins' of the higher levels of government. Indeed, major decentralisation 'reforms' in PNG in 1995 impacted adversely on the powers and service abilities of the LLGs even though the 'reforms' were justified in terms of decentralisation to LLGs (May 1999), while in Solomon Islands the local level system of Area Councils created at Independence was largely ignored at the national level (Nanau 1998, p.190) and then abolished in 1996/7 (Cox and Morrison, 2004). At the same time those 'reforms' did little to enhance the presence or effectiveness, at the local level, of the other levels of the state - Provincial and National government.

In the absence of effective formal local government, most villages and communities have governed their affairs according to customary rules and localised practices that have evolved and adapted over time. In PNG there were wide variations in the ways clans organised and conducted socio-political affairs in their villages and communities, consistent with that country's immense diversity in local languages, cultures and topography (Rowley 1965, pp. 32-52; Jinks 1971, pp. 8-37). In the smaller polity of Solomon Islands it was possible to identify 'traditional governance structures' that provided its small discreet 'tribal' units with a framework for social and economic relations, leadership and participation (Wairiu and Tabo 2003; White 2007).

The absence of effective local government, however, has not left communities in either country totally bereft of services. Services such as schools and health clinics, normally provided by governments, continue to be supplied by church missions, although the coverage is neither evenly spread across both countries nor sufficient to cater for all but a minority of the population. Mining companies, particularly in PNG, have contributed to 
the building and repair of roads, bridges and wharf facilities, and have initiated local business development ventures in the areas where their businesses are located. International non-government clubs and organisations have built and resourced schools and clinics - a recent hospital at Kokoda, for example, being a gift from Australian Rotary Clubs.

Importantly, one institution of government that has become reasonably well embedded at the local-level across most of PNG has been that of Village Courts. These are disputeresolution mechanisms that operate under state authority - though often autonomously of the state - with local assessors adjudicating cases, the outcomes of which are highly contextualised and consequently of considerable local credibility and legitimacy.

Over the past decade, researchers and participant-observers have looked beyond the formal institutions of government and examined more broadly the governance-related political and community activity that is occurring at local levels, in a sense, in the absence of state. A significant finding in both countries - and the major concern of this article - has been the formation and flourishing of large numbers of local-level groups and associations that have organised in pursuit of governance, development and community-related activities and objectives. Anwar Shah provides a helpful distinction between these terms: local government referring to specific institutions or entities created constitutionally, legislatively or by executive order to deliver a range of specified services to a relatively small geographically delineated area; whereas local governance refers to a broader concept defined as the "formulation and execution of collective action at the local level" encompassing both "the direct and indirect roles of formal institutions of local government ... as well as the roles of informal norms, networks and community organizations, and neighbourhood associations in pursuing collective action ....” (Shah 2006, pp. 1-2).

\section{Condition of local level government}

The poor condition of LLG in PNG was described in 2004 by the then Minister for InterGovernment Relations, Sir Peter Barter, in the following terms:

“... LLGs have proliferated without regard to cost and cost-effectiveness. At the same time, local government councils (with honourable exceptions) have lacked financial discipline. Much of their external income has disappeared into councillors' salaries and allowances. Much of their internal revenue, which has been derived from fees and 
rentals, has been siphoned off by councillors and public servants” (Barter 2004, p.146). ${ }^{1}$

In May 2005 Minister Barter was similarly critical of the abuse of LLG funding, estimating that perhaps 80-85 per cent was “either 'wasted' or not used for its intended purpose, through lack of proper planning or corruption” (in May, RJ, 2005, p. 2). He was critical also of the fact that more than half the provincial administrators were 'political' appointees who often had no experience of running a province or a local-level government and called for the reintroduction of a merit-based career service structure.

A 'Pilot Study of District Level Governance in Papua New Guinea' conducted in 20042005 by researchers from Divine Word University, the National Research Institute of PNG and the Australian National University in four of the 19 Provinces (May, Ron 2005; Haley 2005) pointed to variations in performance across the country and to recurring problems of funding, infrastructure, human resources and the roles played by MPs. In a number of cases, the study found that LLGs were ineffective, 'if indeed they met at all'! The study reached conclusions about the performance of many District and LLGs equally as critical as those of the Minister, although they were expressed in less blunt language.

That sorry condition has persisted. Philip Moya (2007, p.166), himself a former senior provincial administrator in PNG described how provincial governments had "hijacked the due processes of planning, budgeting, accounting and reporting ... and derailed the proper constituted procedures and mechanisms to ensure that all stakeholders participate. The losers (Moya continued) have been the vast majority of the population. Good road networks, communications, health facilities, and goods and services have been denied to 85 percent of the provincial population, who depend entirely on the subsistence economy.” Diana Cammack (2008), in a report on 'Chronic Poverty in Papua New Guinea' for the Chronic Poverty Research Centre, noted 'disfunctionalities' in local administration, insufficient funding for local projects, politicised appointments of staff, and lack of either upwards or downwards accountability. A Senior Fellow at the National Research Institute in PNG, Dr Alphonse Gelu (in Eves, forthcoming; see also Esonu,

\footnotetext{
${ }^{1}$ A prominent exception in PNG is the Province of East New Britain (May, Ron, June 2005); while in Solomon Islands local government ie effective in the Province of Santa Isabel (White 2007; Nanau, Waleanisia and Wickham 2005).
} 
2006), reckons that very few of the three hundred and three LLGs in the country operate effectively.

In both countries the presence of the 'state' was thin. Public servants rarely travelled away from provincial headquarters and the local member of Parliament (whose constituency was likely to geographically cover several LLG units) nominally became the representative of the state. In Solomon Islands, Cox and Morrison (2004) noted that in the absence of a local tier of government following the abolition of Area Councils, a 'gap' between the provincial administration and the local-level had developed that had been exacerbated by the closure of many provincial sub-stations due to financial cuts associated with the period of 'ethnic tension’ from the late 1990s. Scales (2005 p.141-2) noted the constant complaints and frustrations of rural Solomon Islanders at the lack of meaningful institutional change or reform and of their desire for government's recognition and support for the many village-based associations which informally act as service deliverers. From another angle, donors have recently expressed frustration at the absence of local government authorities or a workable decision-making structure through which they could disburse donor-relief funding following a tsunami! (Ladley, 2009)

The trauma, turmoil, disruptions and dramatic economic downturn of the period of tension and crisis (1999-2003) in Solomon Islands that led to an armed intervention known as the Regional Assistance Mission to Solomon Islands (RAMSI), have contributed even further to a falling away of government at the local level. A communitylevel 'Snapshot' of Solomon Islands for the AusAID-sponsored 'Community Sector Program' in 2005/6 found wide separations and disjunctions between communities and the formal structures of government (Lawrence and Allen in Eves, forthcoming). Access to government services was seen as low, police involvement slight, and conflict resolution left to chiefs and churches. MPs' visits to their constituencies, beyond their home area, were rare.

While there has been a falling away of government at the local level, there has been no shortage of politicking. Attempts by governments in both countries to disperse more funding to rural areas through direct grants to MPs (District Grants in PNG; Rural Constituency Funds in Solomon Islands, the latter funded by aid from Taiwan) have increased the prevalence of 'patronage' politics. These 'handouts' are an unplanned and 
often inappropriate disbursement of cash, which swamp local capacities and warp expectations at the community level. They have led in PNG to antagonisms between the various levels of government and in both countries to fierce politicking for access to this resource.

Reforms to LLG in both PNG and Solomon Islands are not in immediate prospect. Senior PNG government ministers recognize the problems of the current decentralised system and various government agencies including the National Economic and Fiscal Commission and the Public Sector Reform Advisory Group (Government of PNG, 2006; PSRAG Second Report, July 2006) have advised the PNG Government on steps towards LLG and broader governance reform. A public dialogue involving interested groups on fiscal decentralisation is in train, but as yet there has been no strong commitment in policy or resources towards resolving these institutional problems. Reform in Solomon Islands hinges to a large extent on a long-running (but currently faltering) constitutional reform process established to consider the prospects for a federalist state structure known as the 'Constitutional Congress and Eminent Persons Advisory Council'. Among reforms proposed that would affect LLG are the delegation of authority to the provinces (or states) to provide for lower levels of governance as appropriate, and for the constitutionalisation of 'custom'.

\section{Governance activity at the local level: in the absence of state}

The past decade, as noted above, has witnessed a plethora of community-based groups forming in many locations and becoming active across a wide and diverse range of activities in both PNG and Solomon Islands. Collectively these groups may be considered a part of the nation's emerging 'civil society'; a largely indigenous 'organic' process now aided, to some extent artificially, by donor programs and funding which are designed to promote good governance and democracy agendas. ${ }^{2}$

The variety of such groups, associations and organisations is wide. Some operate at national level with knowledge of and connections to government, donors and parts of the private sector. There are many organised, non-government/non-state organisations that approximate the description of a local 'non-government organisation' (NGOs). There are

\footnotetext{
${ }^{2}$ Dinnen (2003 p. 6) discusses the conceptual difficulties in defining 'civil society' and its presumed roles in the political and social development of Melanesia.
} 
even larger numbers of community-level organisations and associations, usually with intensive local foci, that may be categorised as community-based organizations (CBOs). There are similarly based associations that have a bisnis orientation; sometimes resembling old-style, savings-and-loans societies, at other times being more commercially focused. The 'business development associations' of the late-colonial period seem to have faded from fashion. (The Australian Council for International Development estimates there to be 57 Australian NGOs in PNG and 20 in Solomons; 20 'registered' local NGOs in each country; and hundreds of CBOs.)

Churches of various denominations, in themselves perhaps the strongest NGOs, are widespread across Melanesia and have spawned (and operate in tandem with) other associations, particularly women's clubs and groups. As noted above they fulfil a quasigovernmental role in health and education service delivery across Melanesia. Women's groups and associations are numerous - Alice Pollard and colleagues estimating that about 3,000 community women's groups and 10 or more women's associations operate at the national level in Solomon Islands (Wairiu, 2006; see also Wairiu 2003, Scales 2003). At village and clan level, self-help groups designed to improve the lot of the community by organising collective services and activities - marketing, clinics, village improvements, roads, and dispute resolution - are also in evidence (Hegarty and Thomas, 2005). ${ }^{3}$ Issue-oriented NGOs are active, for example, over land, forestry and environmental concerns (often linked to international NGOs) and operate not simply in 'protest' fashion, but in support of local development objectives as well as conservation. Many local groups and associations exist (in PNG) in the 'shadow' or in place of former Local Government Councils (LGCs). Some continue to conduct the business of the LGC (for example: meet, plan, receive and debate submissions from ward committees; issue instructions and fine 'offenders' for transgression of local rules of behaviour, such as unleashed pigs, showing disrespect to others, and trespassing; and carry out minor works and repairs to buildings and local roads) even though the councils have not operated formally for a decade or more.

Some groups exist alongside, or morph into, or draw inspiration from groups that bear some resemblance to the so-called 'cargo-cults' of previous decades (Regan, Cox and

\footnotetext{
${ }^{3}$ Note that some self-help groups formed also in the 1970s in the period around PNG's independence. Current group formation is different from the anti-colonial mobilisations of the early 1970s. May, 1982.
} 
Bainton, forthcoming). And in parts of Melanesia there are specifically designated and increasingly self-designated fighting groups and/or 'raskols' that engage in retribution and/or criminal 'gang' activity and which may be seen, in the broad, as negative social capital, though at times in the local context, as functional providers of 'security'.

An interesting sub-category of associations, or communities, are those which stand outside the 'system' - deliberately absenting themselves from 'engagement' with government, though occasionally, but quite autonomously, making contact with the state/government apparatus when it suits their particular interest or need (Minnegal and Dwyer in Eves, forthcoming 2009).

In the nature of Melanesian social organisation, most community groups - if not all will have a clan or sub-clan base. Leadership of these groups is as yet an underresearched subject; but aspiring big-men, motivated women, those with a service orientation and (doubtless) those - young and old - with an eye on the political prize of a seat in Provincial Assemblies or National Parliament.

The rationale and objectives of these groups and associations are varied, but all involve some form of local-level organisation and most have the objective of improvement in the livelihoods and socio-economic conditions of the rural populace, as well as of the preservation of 'kastom', tradition and 'ways of life'. Many link to church networks to enhance effectiveness. Increasing numbers of groups across the spectrum are accessing donor funding, thereby requiring some degree of formal organisation and 'paperwork' Mobilisation around local issues and the charting of agendas for the enhancement of livelihoods and service delivery, all indicate degrees of politicisation and forms of 'civic' action that often go unrecognised by analysts, donors and even at times by those in power locally. The absence of an effective local governmental system has denied these groups a 'channel', theatre, decision-making apparatus and resource provider/allocator within which they might operate, or with which to interact more effectively on behalf of their 'constituents'. Such an absence also leaves them frequently vulnerable to being bypassed by patronage politicking on the part of the elected national MP, thereby limiting their clout and functionality.

\section{Local-level groups and associations: case studies}


Most local group and community initiatives are not well known. To illustrate some of their character and diversity the next section of the paper briefly summarises some case studies presented in the main by the organisers themselves in conferences and workshops organised by the State, Society and Governance in Melanesia program of the Australian National University since 2004. It is by no means a comprehensive sample of the types of groups and associations concerned with governance, community service, confidence building, resource development and entrepreneurial activity occurring at the local-level.

A community and development activist in the Highlands of PNG, James Ogia (2008), related his stori of how he and his wife set about building 'collective responsibility' in their remote village by 'tapping traditional notions of group benefit for modern needs'. Their task was to: bind together 12 villages (3,500 people, speaking different languages) in a remote area of the PNG's Eastern Highlands province (90 kms from Goroka) that had had no 'development project' or maintenance of the school or health clinic since independence in 1975. The community was also close to separating out along individual clan lines as a result of growing mistrust (loss of bonding 'social capital') as a result, for example, of the younger generation not understanding cultural mores including 'wrong' or unsanctioned marriages.

The Ogias founded the Pamusa Community Development Association in 2002. It utilised the former council ward structure to select its leadership group (thus allowing the 'big men' of the several communities to maintain their 'customary' status and roles). Awareness raising was conducted from 2002 to 2004, after which the majority of people agreed to associate. Key community functions included: roads maintenance, clean water supply, education and health clinic infrastructure, farming and cash-crop improvements, limiting vandalism, emphasising the value of communal effort, and marketing produce to Goroka. Problems encountered included: the loss of skilled and educated members (to towns); local power plays and jealousies often involving elements of 'kastom' and longstanding rivalries; and the fact that the 'drivers' of change needed to be consistently present. Some donor support was received, for example, for a nutrition program from the Save the Children fund (Ogia, 2008).

A senior lay official of the Church of Melanesia in Solomon Islands, Ms Ollie Pokana (2008) who manages the 'Inclusive Communities Program', described a Church-run 
outreach program with donor funding support designed to build community confidence in the period following the 'ethnic tension'. The program is aimed at strengthening villages' capacities for economic self-reliance, leadership, reconciliation and poverty reduction. Training, counselling, mentoring, and representational activities included literacy programs, a 'youth parliament', collaboration amongst 'Houses of Chiefs', critiques of mining and logging ventures, and prisoner rehabilitation programs for lifeskills and reintegration. (See also, Higgins 2008).

A local-level health worker, Ms Marilyn Peri (2008), provided an account of a program which built community health care centres in the Southern Highlands Province of PNG a province that had suffered an almost total collapse of services and been subjected to armed violence on a near constant basis for the past decade. The program, supported by the Church of Nazerene, developed the capacity of hundreds of volunteers to provide health and education training, self policing (through local peace officers) and incomegeneration advice to communities. It helped bond clan alliances, formulated requests for government assistance, and played an important role in developing self-reliance and collective responsibility in various parts of the Province.

Eric Kwa (2008), an academic and lawyer at the University of PNG, described his role in public advocacy, education and legal support in assisting a LLG in Madang Province to counteract a startling rate of deforestation in the area. In the process, concepts of 'natural resource governance regimes' were developed such that landowners became aware of the consequences of natural resource plunder; were enabled to extract a fair share of revenue and royalties; were aware of the need for 'forestry protection' through legislation; and began to codify customary laws and strengthen collaboration between landowners of various kinds such that a new landowning category - 'grass-land owners' - became important in considerations of resource development.

Rural development specialist, Freddie Hombuhanje (2008), presented a case study of World Vision’s ‘Begasin Bugati Rural Development Program’ in PNG - a large program targeting 40,000 rural inhabitants in Madang Province aimed at improving health, food security and economic status, and the capacity for self-management. This program involves strong partnerships with government departments (including the national 
government's Department of Agriculture, Livestock and Fisheries), research institutes, LLGs, and public education radio programs.

Tingneo Mandan (2005), a former school headmaster, described his leadership efforts and those of his community in the 'las kona' (last corner) of the Morobe Province in PNG to achieve 'development through self-reliance'. His stori tells of a group of villages in an isolated inland area that stopped paying taxes to its LLG (distantly located in another valley) and then invested savings in small business ventures to accumulate capital in the provincial capital, Lae, and then in bulldozers so as to build an airstrip and clear roads for the transport of produce from their Burum valley to larger markets. He recounts the sending of students to institutions outside the region for higher education, and of their return to teach in local schools. His stori is an exemplar of community initiative for self-reliant development.

Two urban settlement leaders, Issac Wai and Paul Maia (2005), recounted their efforts to bring peace and order to the so-called 'squatter settlement' in which they lived in Port Moresby - a multi-cultural/multi-ethnic settlement racked by anomic and criminal behaviour - by forming a 'Peace, Good Order and Community Development Association'. The association comprised leaders from the 34 ethnic communities and set about implementing counselling and instructional programs on, for example, the prevention of delinquency, the promotion of human development, the status of women, HIVAIDS prevention, conflict mediation and restorative justice, and sports participation for its communities. Liaison arrangements were established with the PNG Police Force and a high degree of order and community cooperation was achieved.

Francis Koburu, a village leader from the Marau area of eastern Guadalcanal, Solomon Islands - a particularly conflicted area during the period of 'ethnic tension' - recorded instructively the ways by which communities restored peace and rebuilt relationships by drawing on, and expanding upon, 'traditional' governance, without the central state playing a role. The Marau Community Association took responsibility for rebuilding the school and health centre and for accessing donor funds for small development projects (piggery, copra dryers), and in effect created an informal local level governance system. As elsewhere, there is a growing preference within local communities, in the absence of 
the central state playing a development and service provision role, to work directly with donors (Koburu and Wairiu 2008).

The above cases offer only a small sample of the literally hundreds of groups, 'komitis' (committees) and associations that are active at local levels throughout Melanesia.

\section{Significance?}

What is the significance of this range of activity for Melanesian politics and governance when the state's presence and authority at local levels is weak and undeveloped? Does it foreshadow the emergence of 'citizen politics', the 'voice of the people', the 'demand' for better governance, or the 'forward thrust of civil society' that democracy builders and donor agencies hope will invigorate the political and policy processes at both local and national levels, thereby deepening democracy, improving government, and bringing a sense of both nationhood and citizenship? Or is the long-known antipathy to the state of Melanesia's small-scale, acephalous segmentary societies, together with the difficulty they have in combining/coalescing for collective action, likely to frustrate such political development?

There is as yet no consensus on these broad questions among commentators interested in state and nation building in Melanesia. Most scholars and practitioners in the region are cautious in their assessments of this expanding group activity. Anthropologist Lawrence Goldman (2004, p.12) observed of the Southern Highlands Province in PNG that: "Perhaps the hardest task will be to overcome distrust of, and disrespect for, all forms of state governance which is seen as a cannibal of landowner protein." And "Whilst politics is perceived as patronage rather than as participatory endeavour ...” formal systems of government will gain little traction.

Ian Scales (2005 p.140), an anthropologist and consultant, observes Solomon Islands societies as having their 'own varied solutions to self-governance' and suggests perhaps a 'poly-centric' model of government might need to be invented! Scales also argues for the better articulation of these kinds of organisation with the state, which may do more for development through broad-based participation than would 'federalising'. 
Melanesian analysts point to 'pragmatism' as a driving force within communities. Morgan Wairiu (2006 p.415) writes that communities respond to programs that assist in livelihoods development; not to the more abstract (as far as they are concerned) programs that address the functions of the state apparatus. Naihuo Ahai (2008), in summing-up the Participatory Governance: Whose Voice? conference in Madang in July 2008, notes that communities have great difficulty in conceptualising 'governance', 'voice' and 'participation' - one of the dominant agendas of donors in their efforts to improve democratic governance. He too noted that communities' understanding of 'governance' is pragmatic and functional: 'service delivery' is the 'number one' expectation and understanding. Hence in his view the link is to organised government, not to political governance. Fr Pat Gesch (2008), a scholar at the Divine Word University in PNG, sees donors (and governments) 'tinkering around the edges' until such distant time as the link between village and government is made. Much dialogue around civil society, he suggests, is wishful thinking, especially when most Melanesian villages do not have functioning roads, schools, clinics, water and power.

David Hegarty and Anthony Regan (2005) of the State, Society and Governance in Melanesia Program (SSGM) at the ANU, observed a rapid growth in the stock of social capital and an expansion of 'transactions', 'interactions' and 'emerging networks' in contemporary Melanesia; but emphasised the difficulties groups have in collective action, in 'connecting' with government, as well as the long timeframes involved in the growth of civil society and its impact on governance. A World Bank analyst, Bruce Harris (2007), has a positive interpretation of this emerging civil society in Melanesia seeing it as an intersection: 'Where the Top meets the Bottom'. Oxfam researcher, Chris Roche (2008), echoes Harris in seeing the same intersection or meeting place, but embraces enthusiastically the 'small success stories' about local groups and associations (some of which are described by the practitioners above), which he suggests provide clues for donors and national governments to build upon.

The churches are often viewed as the strongest element of civil society and as providing the civil society alternative to the state. Debra McDougall $(2008, \mathrm{p} 15)$ concludes that, for Solomon Islands, churches "are not ersatz states and cannot be easily harnessed for secular agendas"; but given their strength at the local level "a better goal might be to help foster productive relationships between church organisations and state institutions”. 
Joseph and Beu (2008) speculate on the ability of churches to 'fill the gap' should government collapse in Solomon Islands and suggest that such an outcome is theoretically possible, but would not be sought by churches themselves.

SSGM Fellow Nicole Haley's (2008 p.19-20) recent comparative research on donors' efforts to 'build demand for better governance', however, has led her to a cautious but still optimistic conclusion: "Demand for good governance seems to emerge as a byproduct of a robust and vibrant civil society ... promoting community demand for better governance through civil society strengthening is slow, complex, incremental, iterative and a reflexive process dependent upon extensive relationship building and investment in social infrastructure.”

The broader comparative literature on civil society is instructive about its potential to build and strengthen state institutions and responsible governance. Manor (2003) suggests civil society's success in this endeavour hinges to a large extent on the type of governmental regime in which it operates: a state having 'medium-to-high capacity' and being 'accommodative' offering the best prospect. Shah (2006) visits supply-side questions of LLG noting that the most common design embraces fiscal transfers from the centre, with little revenue-raising from the base, which in turn discourages both accountability to local citizens by LLGs and 'buy-in' by those citizens. He urges a 'network facilitator' role for LLGs in developing countries. Francis Fukuyama (2007, 2008), who visited Melanesia in recent times, noted that patronage politics usually defeats local initiatives, so reformers should build upon existing social capital, minimise the control of communities by local elites, and encourage programs that strengthen community driven development. Fukuyama (n.d., p.16) acknowledged the relative strength of civil society in PNG, but observed that "the networks that would allow more collaboration with local government appear not to be in place.” Equally pertinent is his advice to donors that civil society does not work to donor timetables, and that the task of encouraging civil society is more akin to 'gardening' than to 'engineering' (Fukuyama 2007).

In assessing the changes occurring at local level in Melanesia it is important to remember that we are witnessing civil society 'in formation' at the same time as those state structures and institutions inherited at independence are still being moulded by an 
underlying political culture (quite alien to the origins of those institutions). The Melanesian countries' social and cultural heterogeneity, their developing but fragile economies, their evolving political cultures in which patronage-style politics has become prominent, the difficulty communities have in mobilising around political and governance issues, and the scarcity of communication channels for articulating demands, all constitute significant constraints on the growth and impact of civil society and on the effectiveness of government at the local level.

\section{References}

Ahai, Naihuo 2008, 'Connecting communities with government: Political will, bureaucratic capacity and collective responsibility', in Haley, Nicole (forthcoming)

Bainton, Nicholas A 2008, 'Are you viable? Personal avarice, collective antagonism, and grassroots development in Papua New Guinea', SSGM Seminar paper, 17 July (forthcoming as an SSGM Discussion Paper), Australian National University, Canberra.

Barter, Sir Peter 2004, ''Blunt assessments, hope and direction: lower level government in Papua New Guinea' in Sullivan, Nancy (ed.), Governance Challenges for PNG and the Pacific Islands, Divine Word University (DWU) Press, Madang.

Cammack, Diana 2009, Chronic Poverty in Papua New Guinea: Background Paper for the Chronic Poverty Report 2008-09, Chronic Poverty Research Centre, Manchester.

Cox, John and Morrison, Joanne 2004, Solomon Islands Provincial Governance Information Paper, Report to AusAID, accessed 30 April 2009, AusAID, Canberra, $<$ http://www.ausaid.gov.au/publications/pdf/sols_provincial_gov.pdf>

Esonu, Bernard 2006, Local-level government performance in Papua New Guinea: A case study of Wampar Local-level Government in Morobe Province, Development Bulletin 70, April, Oceania Development Network, Apia, accessed 30 April 2009, $<$ http://devnet.anu.edu.au/db\%2070-\%20pdfs/DB70.pdf >

Dinnen, Sinclair 2003, 'Civil Society and the maintenance of peace and good order in Papua New Guinea', FDC, SSGM, USP Development Research Symposium, Governance in Pacific States: reassessing roles and remedies, Australian National University, Canberra, accessed 30 April 2009, <http://rspas.anu.edu.au/papers/melanesia/conference_papers/2003/3Dinnen_revised.pdf>

Eves, Richard (forthcoming), 'Governance at the Local Level: Melanesians Responding to Governance Issues', SSGM, Australian National University, Canberra.

Fukuyama, Francis 2008, Observations on State-Building in the Western Pacific; Governance Reform in Papua New Guinea; State-Building in Solomon Islands, Johns Hopkins School of Advanced International Studies, Washington, accessed 30 April 2009, <http://www.saisjhu.edu/faculty/fukuyama/Melanesia2> 
Fukuyama, Francis 2007, Civil Society and Improved Governance in Developing Countries, Keynote Address at the Brookings Institute and the Johns Hopkins School of Advanced International Studies, March 20, 2007, Washington, accessed 30 April 2009, $<$ http://www.internationalbudget.org/resources/library/Fukuyama.pdf >

Gesch, Fr Pat 2008, Participatory Governance? in Haley, Nicole (ed.), forthcoming.

Government of PNG 2006, Public Sector Reform Advisory Group, Second Report: Improved Decentralisation - Getting People Involved in Democracy, Strong Civil Society, Peace and Good Order, and Self-Reliance, Government of PNG, Apia.

Gelu, Alphonse 2008, 'Devolution of administrative powers to Provincial Governments: Its implications on governance at the lower level governments', in Eves, forthcoming.

Goldman, Lawrence 2003, 'Hoo-Ha in Huli': Considerations on Commotion and Community in the Southern Highlands Province of PNG, SSGM Discussion Paper 2003/8, Australian National University, Canberra.

Haley, Nicole 2005, 'District Government - Information Collection Report, 20 April 2005', Australian National University, Canberra, accessed 40 April 2009, $<$ http://rspas.anu.edu.au/papers/melanesia/conference_papers/0506_PNGDistrictGovernance_SH P_infocollection.pdf>

Haley, Nicole 2008, 'Strengthening Civil Society to Build Demand for Better Governance in the Pacific: Literature Review and Analysis of Good Practice and Lessons Learned', SSGM Discussion Paper 2008/7, Australian National University, Canberra, accessed 40 April 2009, $<$ http://rspas.anu.edu.au/papers/melanesia/discussion_papers/08_07.pdf>

Haley, Nicole (ed.) forthcoming: Participatory Governance - Whose Voice? Workshop on participatory governance initiatives, held at Divine Word University, Madang, PNG, 30 June - 1 July, 2008. Co-organised by World Vision and SSGM, Australian National University, Canberra. Harris, Bruce M 2007, Papua New Guinea: A Nation in Waiting - The Dance of Traditional and Introduced Structures in a Putative State, East Asia Environment \& Social Division, The World Bank.

Hegarty, David and Thomas, Pamela (eds) 2005, Effective Development in Papua New Guinea, Development Bulletin No. 67, April, Oceania Development Network, Apia, accessed 30 April 2009, http://devnet.anu.edu.au/db67.php>

Hegarty, David and Regan, Anthony 2005, Papua New Guinea: Weak state, strong society in Hegarty and Thomas, Australian National University, Canberra, pp. 110-112.

Higgins, Kate 2008, Outside-In: A Volunteer's Reflections on a Solomon Islands Community Development Program, SSGM Discussion Paper 2008/11, Australian National University, Canberra.

Hombuhanje, Freddy 2008, Empowering local representation through Ward Development Committees: Lessons Learned from the Begasin Bugati multi-sectoral project, Madang province, $P N G$, in Eves, Richard (forthcoming) 
Jinks, Brian 1971, New Guinea Government: an introduction, Angus and Robertson, Sydney. Joseph, Keith and Beu, Charles Browne 2008, Church and State in Solomon Islands, SSGM Discussion paper 2008/11, Australian National University, Canberra.

Koburu, Francis and Wairiu, Morgan 2008, Forty-six years of living in the village: Our experience in governance at local-level in Hatare Community, Solomon Islands, in Eves, Richard (forthcoming).

Kwa, Eric 2008, 'Forestry governance: providing a legal framework for individual community decision-making', in Haley, Nicole (ed.) (forthcoming).

Lawrence, David and Allen, Matthew 2008, “A Snapshot of Local Level Governance in Solomon Islands" in Eves, Richard (forthcoming).

McDougall, Debra 2008, Religious Institutions as Alternative Structures in Post-Conflict Solomon Islands? Cases from Western Province, SSGM Discussion Paper, 2008/5, Australian National University, Canberra.

Mandan, Tingneo and Holzknecht, Hartmut 2005, 'Nanak mutuk: Development through selfreliance in the Burum Valley', in Hegarty and Thomas, Australian National University, Canberra.

Manor, James 2003, 'Analysing and Reconceptualising Civil Society', Australian National University, $\quad$ Canberra, $\quad$ accessed $\quad 30 \quad$ April 2009, <http://rspas.anu.edu.au/papers/melanesia/conference_papers/2003/1Manor_revised.pdf>

May, R.J. ed. 1982, 'Micronationalist Movements in Papua New Guinea', Political and Social Change Monograph 1, Research School of Pacific Studies, Australian National University, Canberra.

May, R.J. 1999, 'Decentralization in Papua New Guinea: two steps forward, one step back', Ch. 6, pp123-148, in Turner, Mark (ed.), Central-Local Relations in Asia-Pacific; Convergence or Divergence?, Macmillan Press, London.

May, Dr Ron 2005, 'District Level Governance in Papua New Guinea: Preliminary Report of a Pilot Study', SSGM Report, 17 June, Australian National University, Canberra, accessed 30 April, $<\underline{\text { http://rspas.anu.edu.au/papers/melanesia/conference_papers/0506_PNGDistrictGovernance_pilo }}$ tstudy.pdf $>$

May, R.J. 2005, 'SSGM/NRI Project Report on Workshop District-Level Government in Papua New Guinea', 24 June 2005, SSGM, Australian National University, Canberra, accessed 30 April, $<\underline{\text { http://rspas.anu.edu.au/papers/melanesia/conference_papers/0506_PNGDistrictGovernance_repo }}$ $\underline{\text { rt.pdf }>}$

Moya, Philip 2007, 'An Inside Post-mortem on the Southern Highlands: A perspective from Tari’, Ch. 14 in Haley, Nicole \& May, Ronald J (eds), Conflict and Resource Development in the Southern Highlands of Papua New Guinea, ANU E Press, Canberra.

Nanau, Gordon 1998, in Larmour, Peter (ed.), Governance and Reform in the South Pacific, National Centre for Development Studies Policy Paper 23, The Australian National University, Canberra. 
Nanau, Gordon, Waleanisia, Joseph and Wickham, Ashley 2005, 'Isabel Province Development Project (Human Resources Capacity Building \& Rural Service Delivery Assessment)', Consultancy Report, Sept, Australian National University, Canberra.

Ogia, James 2008, 'Collective responsibility: Tapping traditional notions of group benefit for modern needs', in Haley, Nicole (ed.), Participatory Governance - Whose Voice?, forthcoming.

Peri, Marilyn 2008, 'Community-based health centres in Tari, Southern Highlands Province, PNG. Harnessing local capacity for remote development and governance.' In Haley, Nicole (ed.), Participatory Governance - Whose Voice?, forthcoming.

Pokana, Ollie 2008, 'Building Community Leadership Skills: Whose Voice? (Inclusive Communities Program - Anglican Church of Melanesia, Solomon Islands), in Haley, Nicole (ed.), Participatory Governance - Whose Voice?, forthcoming.

Pupune, Steven 2005, 'Blue Corner Farm Business Group' in Hegarty and Thomas (eds), Australian National University, Canberra, pp. 17-18.

Regan, Anthony J 2003, 'An Outcomes Perspective on Civil Society in Melanesia: reflections on experience from Bougainville', FDC, SSGM, USP Development Research Symposium, Governance in Pacific States: reassessing roles and remedies, Australian National University, Canberra, $\quad$ accessed $\quad 30 \quad$ April, <http://rspas.anu.edu.au/papers/melanesia/conference_papers/2003/2Regan_revised.pdf>

Regan, Anthony J 2005, 'Clever people solving difficult problems: Perspectives on weakness of the state and nation in PNG', in Hegarty and Thomas, Australian National University, Canberra, pp. 6-12.

Regan, A.J. (ed.) (forthcoming), 'Reform of Decentralisation and Sub-National Fiscal Policy in Papua New Guinea', SSGM, ANU, Canberra. (Collection of papers from Workshops with the same title held in Pt Moresby, PNG, 28-30 April, and in Canberra, 7-8 May).

Regan, Anthony; Cox, John; Bainton, Nicholas (forthcoming), Parallel States, Parallel Economies: Legitimacy and Prosperity in Melanesia, Australian National University, Canberra.

Roche, Chris 2008, 'A Night in a Tent with a Mosquito?', Oxfam Australia, paper presented at Melbourne University, 25 July, 2008.

Rowley, C.D. 1973, The New Guinea Villager, Cheshire, Melbourne.

Scales, Ian 2005, 'State and local governance in Solomon Islands: building on existing strengths', Pacific Economic Bulletin, Vol. 20 No. 2, pp. 140-148.

Scales, Ian 2003, 'The Flourishing of Local Level Governance after the Coup in Solomon Islands: Lessons for Reform of the State', SSGM/USP/FDC Conference, Suva, October. Accessed 30 April, 2009,

$<$ http://rspas.anu.edu.au/papers/melanesia/conference_papers/2003/13Scales_revised.pdf $>$

Shah, Anwar with Shah, Sana 2006, 'The New Vision of Local Governance and the Evolving Roles of Local Governments', World Bank, accessed 30 April 2009, 
$<\underline{\text { http://siteresources.worldbank.org/INTWBIGOVANTCOR/Resources/NewVisionofLocalGover }}$ nance.pdf $>$

Wai, Isaac and Mai, Paul 2005, "What we did in Saraga: Building community peace and harmony', in Hegarty and Thomas, Australian National University, Canberra, pp. 53-5.

Wairiu, Morgan and Tabo, Steward 2003, Assessing Community Perspectives on Governance in Solomon Islands, a Report for ADB (RETA 6065), October.

Wairiu, Morgan 2006, 'Governance and Livelihood Realities in Solomon Islands', Ch. 23 in Firth, Stewart (ed.), Globalisation and Governance in the Pacific Islands, ANU-E Press (for SSGM).

Walters, Noel, H 2007, 'A brief overview of Government, Law and Order, and Social Matters in the Tari District', Ch. 10 in Haley, Nicole and May, Ronald J, 2007, Conflict and Resource Development in the Southern Highlands of Papua New Guinea, ANU E Press.

Whimp, Kathy 2008, Desperately seeking services? A case study of the political dimensions of fiscal decentralization in Papua New Guinea, unpublished paper, June.

White, Geoffrey 2007, 'Indigenous Governance in Melanesia', SSGM Discussion Paper, 2007/5, Australian National University, Canberra. 